\title{
Physical Fitness Level and Nutrition Status of Darussalam Aur Duri Islamic Boarding School Students
}

\author{
Al Arif Rahman ${ }^{1 *}$, Wilda Welis ${ }^{1}$, Pudia M. Indika $^{1}$, Arsil $^{1}$ \\ ${ }^{I}$ Sport Science Faculty, Universitas Negeri Padang, Indonesia \\ "Corresponding author. Email: alarifrahman05@gmail.com
}

\begin{abstract}
The problem in this study was the lack of knowledge of the physical fitness and nutritional status of the students of Darussalam Aur Duri Islamic Boarding School in X District Koto Singkarak Solok Regency. The purpose of this study was to determine the level of physical fitness and nutritional status of students of Darussalam Aur Duri Islamic Boarding School in X District Koto Singkarak Solok Regency. This type of research is descriptive. The population in this study were Santri Darussalam Islamic Boarding School of Darussalam Aur Duri District X Koto Singkarak Solok Regency which amounted to 194 people. The sample in this study were 36 people taken by Purposive Sampling. Data collection for physical fitness using the TKJI 2010 test aged 13-15 years and nutritional status was carried out by nutritional anthropometric tests. Data were analyzed using descriptive statistics in the form of percentage formula $\mathrm{P}=\mathrm{F} / \mathrm{N}$ x $100 \%$. The result shows that: 1) The physical fitness level of the santri is very low; 2) The physical fitness level of female students is classified unsatisfactory; 3) Nutritional status of male students is categorized lack; 4) The nutritional status of female students is included in the Normal category.
\end{abstract}

\section{Keywords: Physical Fitness, Nutritional Status}

\section{INTRODUCTION}

Sport is one of the important and strategic elements in the process of Indonesian nation-building In addition, sports can improve the quality of human resources, development, economic, socio-cultural, political, defense and security, and increase national productivity and efficiency, to address and overcome challenges and take advantage of opportunities in increasingly global human civilization.

As stated in RI Law No. 3 of 2005 concerning the National Agricultural System Chapter II Article 4 (2005: 6) are: "Sport aims to nurture and improve health and fitness, achievement, human quality, instill human moral and moral values, sportsmanship, discipline, strengthen and foster national unity and integrity, strengthen national resilience, and uplift the nation's dignity and honor" [1].

Based on the quotation above, sport in Indonesia functions as maintaining and improving health and physical fitness. This is an effort to improve the quality of Human Resources, a person will not get good results without being accompanied by good physical fitness. Thus, in order for achieve a good quality of human resources, good physical fitness supporting factors are needed.

Physical fitness is a condition that is very valuable for every individual in carrying out their daily routine. Someone who has a good level of physical fitness do their activities optimally and efficiently, and still be able to do other activities without experiencing fatigue, and vice versa. " physical fitness is an aspect which gives a person the ability to live a productive life and can adjust to each physical load (physical fitness )" [2].

From the description above, it is clear that physical fitness is needed by someone, especially adolescents, which is the forerunner of the next generation, which is expected to grow into quality human resources. Adolescence is a period of growth and is also active in carrying out daily activities such as studying at school, playing and exercising. "Fitness is also inseparable from food factors, because food ingredients are needed by the body for energy sources, the building of body cells, biocatalyst components and metabolism" [2]. Broadly states that nutrition is defined as a process of organisms using food consumed normally through the process of digestion, absorption, transportation, storage, metabolism and expenditure of nutrients to maintain life, normal growth and function of organs and to produce energy. The factors that influence nutritional status are very dependent on daily eating habits because good or bad daily diet results in good or bad nutritional status. Nutritional status is a condition that states the level of nutrition of a person and is also an indicator of nutritional adequacy. High and low nutritional status of a person is determined by food intake consumed every day. If balanced nutrition is of course nutritional status will also be balanced and vice versa. Nutritional status can also determine the level of physical fitness of students to be able to perform physical activities to the maximum. Unbalanced nutritional status 
and poor physical fitness will inhibit activities, physical and motor growth.

Given the importance of nutritional status to improve physical fitness, students who will carry out physical activities in Islamic boarding schools need to consume nutritious food every day before leaving for study and it is very important to pay attention to the balance of these nutritional intake. Islamic boarding school is a traditional education that the students live together and study under the guidance of the teacher or better known as the Kyai. Islamic Boarding Schools are two terms that show one understanding, which is what the santri's place of learning means. Islamic Boarding Schools are also one of the stages of formal education that was established with the aim of educating students to further explore the knowledge of Islam. Islamic boarding schools have several levels of education, namely ibtida iyah, tsanawiyah, and aliyah, where educational activities carried out are different from ordinary school activities, besides they are required to study general sciences they are also required to master the knowledge of religion. Therefore, students who are still classified as teenagers certainly need nutritious food intake every day to meet the body's needs in the process of growth and carry out daily routines. However, based on the results of observations in the field, there are still many conditions in the body of the santri whose growth and development are not as they should have been, even though at this time it was a time when students experienced rapid growth and development. As seen by the presence of santri who are overweight (obese), it looks like that they tend to move slowly and tend to be lazy in carrying out sports activities and teaching and learning processes, as well as santri who have weight below the normal level (thin) also looks lazy in carrying out sports activities and lacks enthusiasm in carrying out the learning process on boarding schools.

The above statement formulated the problem to be examined, namely: the level of physical fitness and nutritional status of students of the Islamic Boarding School Darussalam Aur Duri District X Koto Singkarak Solok Regency. The purpose of the study was to determine the physical fitness and nutritional status of santri Darussalam Islamic Boarding School in Aur Duri X Koto Singkarak, Solok Regency

\section{RESEARCH METHODS}

This research is classified into descriptive research. descriptive research is "one type of research that aims to describe systematically, factually and accurately about the facts and nature of a particular population or try to describe the phenomenon in detail" [3], [4].

The research was conducted at Darussalam Aur Duri Islamic Boarding School in X Koto Singkarak District, Solok Regency in December 2016 - January 2017 with a population of 194 students, consisting of 127 male students and 67 male students. For more details, it can be seen in table 1 below

Table 1. Research Population.

\begin{tabular}{|c|c|c|c|}
\hline \multirow{2}{*}{ Class } & \multicolumn{2}{|c|}{ Students } & \multirow{2}{*}{ Amount Students } \\
\cline { 2 - 3 } & Male & Female & 81 \\
\hline VII & 58 & 23 & 30 \\
\hline VIII & 21 & 9 & 22 \\
\hline IX & 12 & 10 & $\mathbf{1 3 3}$ \\
\hline Amount & $\mathbf{9 1}$ & $\mathbf{4 2}$ & 29 \\
\hline X & 18 & 11 & 15 \\
\hline XI & 10 & 5 & 17 \\
\hline XII & 8 & 9 & $\mathbf{6 1}$ \\
\hline Amount & $\mathbf{3 6}$ & $\mathbf{2 5}$ & $\mathbf{1 9 4}$ \\
\hline Total & $\mathbf{1 2 7}$ & $\mathbf{6 7}$ & Kat \\
\hline
\end{tabular}

Source: Administration of Darussalam Aur Duri Islamic Boarding School in Kabupaten Solok in 2016

Considering the large number of population to be studied, the sampling technique used was purposive sampling, that is the population of aged $13-15$ as many as 40 santri.

The instruments used in data collection was Indonesia Physical Fitness test (TKJI) 2010 for the ages of 13-15 years. The series of tests were as follows, $50 \mathrm{~m}$ fast running, body lift hanging test for men, bending elbow hanging test for women, lying down for 30 seconds, jumping upright and running $1000 \mathrm{~m}$ sons and $800 \mathrm{~m}$ girls later to measure nutritional status using a nutritional anthropometric test, by measuring height and weight. After the data was collected from this study, then the data were analyzed by percentage formula,
Table 2. Male Santri Physical Fitness Level Islamic Boarding School Darussalam Aur Duri.

\begin{tabular}{|c|c|c|c|c|}
\hline No & Value & classification & $\mathrm{F}$ & $\%$ \\
\hline 1 & $22-25$ & Very good & 0 & 0 \\
\hline 2 & $18-21$ & Good & 0 & 0 \\
\hline 3 & $14-17$ & Fair & 0 & 0 \\
\hline 4 & $10-13$ & Poor & 3 & 13,05 \\
\hline 5 & $5-9$ & Very Poor & 20 & 86,95 \\
\hline \multicolumn{2}{|c|}{ Amount } & & 23 & 100 \\
\hline
\end{tabular}

Furthermore, the highest female fitness value was 12 and the lowest value was 7 . Based on the group data, the 
mean was 9.46, standard deviation was 1.51. Furthermore, the physical fitness distribution of the female students of Darussalam Aur Duri Islamic Boarding School in X Koto Singkarak Kabupaten Solok can be seen in the following table:

Table 3. Female Santri Physical Fitness Level Islamic Boarding School Darussalam Aur Duri.

\begin{tabular}{|c|c|c|c|c|}
\hline No & Value & Classification & $\mathrm{F}$ & $\%$ \\
\hline 1 & $22-25$ & Very good & 0 & 0 \\
\hline 2 & $18-21$ & Good & 0 & 0 \\
\hline 3 & $14-17$ & Fair & 0 & 0 \\
\hline 4 & $10-13$ & Poor & 5 & 38.46 \\
\hline 5 & $5-9$ & Very POor & 8 & 61.54 \\
\hline \multicolumn{2}{|c|}{ Jumlah } & & 13 & 100 \\
\hline
\end{tabular}

And the highest nutritional status for men is 21.50 , the lowest nutritional status is 13.85 , mean (mean) 16.70 , and standard deviation (standard deviation) 2.76. Furthermore, the frequency distribution of male santri's status can be seen in the table below

Table 4. Nutritional Status of Santri Male Islamic Boarding School Darussalam Aur Duri Koto Singkarak District X Kabupaten Solok.

\begin{tabular}{|c|c|c|c|c|}
\hline No & Z score threshold & Category & $\mathrm{f}$ & $\%$ \\
\hline 1 & $>-3 \mathrm{SD}$ & Very thin & 2 & 8.69 \\
\hline 2 & -3 SD s/d <-2 SD & Thin & 13 & 56,20 \\
\hline 3 & $-2 \mathrm{SD}$ s/d $1 \mathrm{SD}$ & Normal & 6 & 26.08 \\
\hline 4 & $>1 \mathrm{SD} s / \mathrm{d} 2 \mathrm{SD}$ & Fat & 2 & 8.69 \\
\hline 5 & $>2 \mathrm{SD}$ & Obesity & 0 & 0 \\
\hline \multicolumn{3}{|c|}{ Amount } & 23 & 100 \\
\hline
\end{tabular}

And the highest nutritional status of female is 24.15 , the lowest nutritional status is 13.32 , the mean (mean) is 17.82 , and the standard deviation is 3.03. Furthermore, the frequency distribution of male santri's nutritional status can be seen in the following table:

Table 5. Nutritional Status of Santri Female Islamic Boarding School Darussalam Aur Duri Koto Singkarak District X Kabupaten Solok.

\begin{tabular}{|c|c|c|c|c|}
\hline No & $\begin{array}{c}\text { Z score } \\
\text { threshold }\end{array}$ & Category & f & $\%$ \\
\hline 1 & $>-3$ SD & Very thin & 0 & 0 \\
\hline & -3 SD s/d <-2 & Thin & & 38. \\
2 & SD & & 5 & 46 \\
\hline & -2 SD s/d 1 & Normal & 7 & 53. \\
3 & SD & & 84 \\
\hline & $>1$ SD s/d 2 & Fat & & 8.6 \\
4 & SD & & 1 & 9 \\
\hline 5 & $>2$ SD & Obesity & 0 & 0 \\
\hline \multicolumn{3}{|c|}{ Amount } & 13 & 100 \\
\hline
\end{tabular}

\section{DISCUSSION}

Physical fitness is the main capital aspects of life. In general, humans need physical fitness so that they can work well. Someone who has good physical fitness will be able to do an activity in a long time. At the junior high school level, moreover it is an Islamic Boarding School, of course the teaching and learning activities are not the same duration as ordinary schools. Islamic boarding schools guide the students to learn the knowledge of religion and the sciences studied at school, plus the activities of the santri at night consisting of tadarus, tahajud and memorizing the Kitab Kuning, it is a very dense and tiring activity, that is the activity carried out by the santri every day. It is risky for physical fitness because there is no santri time to do maximum physical activity and it will have a negative impact on health, such as: fatigue, lack of enthusiasm and lack of concentration.

Physical fitness is very important for santri in carrying out daily life, because physical fitness is a person's ability to complete tasks or daily activities without experiencing significant fatigue. A physical aspect of total fitness that gives a person the ability to live a productive life and can adjust to each load or proper physical stress "

From the quote above, it is clear that someone who has good physical fitness will be able to carry out an activity in a long time. Physical fitness in question does not only cover the physical realm, but also mentally, socially and emotionally so that it is total fitness.

Nutritional status is a person's condition caused by consumption, absorption, and use of other substances from food for a long time. so normal nutritional status is very important for someone to carry out daily activities and for their physical growth and development. The factors that influence nutritional status are very dependent on daily eating habits because the good or bad of daily diet will have an impact on a person's nutritional status.

Given the importance of nutritional status for santri, one of the efforts that can be done to overcome the problem for santri who have abnormal nutritional status is that the teacher gives understanding and understanding to the santri about the importance of nutrition, santri to be able to pay attention and consume good nutritious food, as well as the manager Islamic boarding schools as those who serve as providers of food consumption for santri must provide nutritious and varied food to santri.

Referring to the results of the study stating that the physical fitness of santri in the Islamic Boarding School of Darussalam Aur Duri District X Koto Singkarak, Solok Regency was classified as less with an average of 8.69 and the nutritional status of the students was in the less category with an average of 17.10. It was a result that greatly affected the physical fitness and nutritional status of the santri which could hamper daily activities.

When physical fitness and a person's nutritional status are low, it affects his health which makes his mind disturbed, the learning process is disrupted, besides that he will get tired, lack of enthusiasm, sleepiness, illness, not going to school, and not achieving. Santri must have physical fitness and good nutritional status, so that all that is realized santri must work regularly and boarding schools pay more attention to sports facilities so that santri can carry out maximum physical activity. Physical fitness has an important role in daily activities, which will describe the overall fitness related to the ability and ability to 
perform an activity optimally and efficiently, while the low level of physical fitness of a person will have a negative impact on the quality of work everyday Teenagers who have physical fitness levels below the average will usually be lazy to learn and not enthusiastic in carrying out physical activities and students who have abnormal nutritional status, all activities and movements that they do will be hampered. This will later have a negative impact on the quality of human resources, achieving quality human resources quality will be hampered

\section{CONCLUSION}

Based on the results of the research and data analysis above, it can be concluded as follows: 1) Physical Fitness owned by male students of Islamic Boarding School Darussalam Aur Duri District X Koto Singkarak, Solok Regency, of all 23 santri, 20 santri $(86.95 \%)$ had less physical fitness, 3 santri $(13.05 \%)$ had less physical fitness. And none of the male students who have physical fitness is very good, good or moderate, 2) Physical Fitness possessed by female students from the Islamic Boarding School Darussalam Aur Duri District X Koto Singkarak, Solok Regency, of all 13 santri, 8 santri $(61.54 \%)$ have very poor physical fitness while the rest (5 santri) $(38.46 \%)$ have poor physical fitness, and none of the female santri have physical fitness in very good, good or moderate status. 3) Nutritional Status possessed by male students of Islamic Boarding School Darussalam Aur Duri District X Koto Singkarak, Solok District, from 23 santri, there were 2 santri $(8.69 \%)$ who had very thin nutritional status, 13 santri $(56.20 \%)$ who have underweight nutritional status, 6 santri $(26.08 \%)$ who have normal nutritional status, 2 santri $(8.69 \%)$ who have obese nutritional status, and no one has obesity nutritional status. 4) Nutritional Status possessed by female students of Islamic Boarding School Darussalam Aur Duri District X Koto Singkarak Solok District of 13 santri, 5 santri $(38.46 \%)$ who had underweight nutritional status, 7 santri $(53.84 \%)$ who had normal nutritional status, 1 santri $(8.69 \%)$ who has obese nutritional status, and no one has obesity nutritional status. And based on the conclusions above, the suggestions that the author can give are as follows: 1) It is expected that all Santri Teachers of the Darusslam Aur Duri Islamic Boarding School in X Koto Singkarak Subdistrict in Solok Regency can further improve their physical fitness so that they can have a positive impact on carrying out activities daily. The effort that can be done to improve physical fitness is to like to exercise, both in the afternoon and in the morning and arrange food and adequate rest. 2) It is recommended to the teacher / cleric and cleric to pay more attention to the fitness and ideality of the santri's nutritional status. This can be done by checking and controlling fitness and nutritional status and in Islamic boarding schools it is very necessary for sports teachers who will guide students to improve fitness. 3) Students who have technological advancements, whether mobile phones, motorized vehicles, washing machines or other technologies for daily needs so as not to obey the progress, because it will make us lazy to move.

\section{REFERENCES}

[1] Constitution RI No.3. "About the National Sports System". Jakarta: Republic of Indonesia Ministry of Youth and Sports. 2005. pp. 12

[2] A. Agus. "Physical Fitness, As An Introduction". Padang: Sukabina Press. 2012. pp. 27

[3] M. Yusuf. "Research methodology". Padang: Press UNP, 2005. pp. 12.

[4] S. Arikunto. "Research Procedure". Jakarta. Rineka Cipta. 2010. pp. 11. 